Psihologijske teme, 28 (2019), 2, 441-460

Izvorni znanstveni rada

UDC: 159.953 .2 .072

doi:https://doi.org/10.31820/pt.28.2.11

\title{
Efekt privlačenja u vidnom radnom pamćenju
}

\author{
Ivan Tomić, Matej Pavlić, Denis Vlašiček i Dragutin Ivanec \\ Sveučilište u Zagrebu, Filozofski fakultet, Odsjek za psihologiju, \\ Zagreb, Hrvatska
}

\begin{abstract}
Sažetak
Temeljno obilježje vidnoga radnog pamćenja jest da preciznost dosjećanja opada porastom broja podražaja koji se pamti. Ovaj se nalaz tumači kao posljedica raspodjele ograničene količine resursa, pri čemu porastom broja podražaja koji se pamti pada količina resursa pridana svakom podražaju. Nedavna istraživanja pokazuju kako dosjećanje u zadacima vidnoga radnog pamćenja ovisi i o karakteristikama seta podražaja koji se pamti. Konkretno, u zadatku pamćenja jednostavnih vidnih karakteristika dvaju podražaja (npr. orijentacije) dosjećanje jednog podražaja karakterizira sustavna pogreška u smjeru drugog zapamćenog podražaja, tzv. efekt privlačenja. U ovom smo istraživanju željeli provjeriti koliko je ovaj efekt otporan na eksperimentalne manipulacije preciznosti pamćenja podražaja. U četiri su eksperimenta sudionici $(N=33)$ pamtili i dosjećali se istovremeno prikazanih orijentacija podražaja. U prvom je eksperimentu redoslijed dosjećanja odabiran po slučaju; u drugom su eksperimentu sudionici trebali samostalno birati redoslijed kojim će se dosjećati, a u trećem i četvrtom eksperimentu redoslijed dosjećanja ponovno je odabiran po slučaju, no sudionicima je na svakoj sekvenci unaprijed (eksp. 3) ili unatrag (eksp. 4) signalizirano kojeg će se podražaja najvjerojatnije morati dosjetiti prvog. Efekt privlačenja bio je vidljiv u sva četiri eksperimenta, i to pri dosjećanju obaju podražaja. Ovo istraživanje demonstrira robusnost efekta privlačenja u vidnom radnom pamćenju, što implicira da mehanizmi u podlozi tog efekta nisu podložni korekciji, odnosno da su sastavni dio temeljnih procesa kodiranja vidnih podražaja.
\end{abstract}

Ključne riječi: vidno radno pamćenje, efekt privlačenja, pamćenje orijentacija, signaliziranje

\section{Uvod}

Vidno radno pamćenje skup je procesa koji omogućuju kratkotrajno zadržavanje i manipulaciju vidnih senzornih informacija, a smatra se ključnim za

Ivan Tomić, Odsjek za psihologiju, Filozofski fakultet Sveučilišta u Zagrebu, Ivana Lučića 3, 10000 Zagreb, Hrvatska. E-pošta: itomic3@ffzg.hr

Ovaj je rad nastao u okviru znanstvenog projekta E-rudito: Napredni online obrazovni sustav za pametnu specijalizaciju i poslove budućnosti (KK.01.2.1.01.0009.), koji je financiran iz Europskog fonda za regionalni razvoj u sklopu Operativnog programa Konkurentnost i kohezija 2014-2020. 
ispravno funkcioniranje niza drugih procesa, od percepcije do motoričke kontrole. Jedan od istaknutijih teorijskih okvira radno pamćenje definira kao ograničenu količinu resursa koji se fleksibilno dodjeljuju senzornim elementima u svrhu izgradnje njihove efikasne unutarnje reprezentacije (Ma, Husain i Bays, 2014). Unutar tog okvira ograničenje radnog pamćenja ne izražava se u terminima broja diskretnih elemenata koje pojedinac može zadržati u obliku mentalnih reprezentacija nakon što podraživanje osjetnih receptora prestane, već u terminima kvalitete, odnosno preciznosti pamćenja, koja je određena količinom resursa koja se dodijeli određenom elementu.

Ovakav je opis ograničenja radnog pamćenja omogućila prilagodba paradigme odgođenog dosjećanja. Tradicionalni pristup ispitivanju vidnoga radnog pamćenja uključuje zadatak odgođene detekcije promjene, tj. usporedbu dvaju sekvencijalno prezentiranih vidnih prikaza odvojenih kratkim periodom retencije (npr. Allen, Baddeley i Hitch, 2006; Luck i Vogel, 1997). Zadatak ispitanika je binarnom odlukom (da/ne) odrediti jesu li elementi u drugom prikazu identični onima u prvom ili je neki od njih različit, pri čemu elementi mogu poprimiti tek nekoliko kategorijalnih vrijednosti. Novija se istraživanja pak koriste unaprijeđenom paradigmom odgođenog dosjećanja, u koju su uvedeni kontinuirana ljestvica za dosjećanje zadanog obilježja prikazanih podražaja te prikazivanje podražaja $s$ vrijednošću obilježja odabranom iz iscrpnog, kontinuiranog seta mogućih vrijednosti (vidi npr. Wilken i Ma, 2004). Primjerice, kada je riječ o pamćenju orijentacija, zadana orijentacija može poprimiti bilo koji nagib u rasponu od $0^{\circ}$ do $360^{\circ}$, a ispitaniku je u fazi dosjećanja omogućena precizna rotacija prikazanog elementa, uz naputak da njegov nagib izjednači nagibu upamćenog podražaja.

Podaci dobiveni ovom paradigmom prikazuju se kroz distribuciju pogrešaka dosjećanja, odnosno distribuciju ispitanikovih procjena vrijednosti obilježja prikazanog podražaja oko njegove točne vrijednosti. Istraživanja koja su upotrijebila ovu metodologiju u najvećoj se mjeri fokusiraju na promjene u uratku ovisno o broju podražaja koji se pamte, a pokazano je da se ograničenje vidnoga radnog pamćenja očituje u smanjenju preciznosti dosjećanja, odnosno povećanju standardne devijacije distribucije ispitanikovih procjena oko točnog odgovora, koje prati porast broja zadanih elemenata za upamćivanje (Bays, Catalao i Husain, 2009; Bays i Husain, 2008).

Izvori pogrešaka koji doprinose nepreciznosti u dosjećanju su mnogostruki. Primjerice, Bays, Gorgoraptis, Wee, Marshall i Husain (2011) pokazali su da preciznost dosjećanja pada s porastom broja podražaja, a da raste s produženjem vremena prikaza. Točnije, porast preciznosti s produženjem vremena prikaza ovisi o broju podražaja, i to tako da je porast brži za manji broj prikazanih podražaja. Stoga su autori, između ostalog, zaključili da nepreciznost može biti posljedica nepotpunog kodiranja ili ograničenja pažnje. Osim toga, Pertzov, Bays, Joseph i Husain (2013) pokazali su da preciznost dosjećanja ovisi i o trajanju perioda retencije jer produženje tog perioda prati opadanje preciznosti. 


\section{Karakteristike podražaja}

Iako se često implicitno pretpostavlja da uradak u zadacima dosjećanja ne ovisi o specifičnostima podražaja koji se pamte, nezanemariv broj studija pokazuje suprotno. Konkretno, istraživanja pokazuju kako su detekcija i dosjećanje bolji za kardinalne (vertikalne i horizontalne) orijentacije u odnosu na kosokutne orijentacije (Girshick, Landy i Simoncelli, 2011; Pratte, Park, Rademaker i Tong, 2017; Taylor i Bays, 2018; Wei i Stocker, 2017). Pošavši od hipoteze da je vidna percepcija općenito prilagođena statističkoj strukturi vidnih informacija u okolini, Girshick i sur. (2011) su, analizirajući veliki broj fotografija prirode, otkrili statističku predominantnost kardinalnih u odnosu na kosokutne orijentacije, te su pokazali da ispitanici preciznije detektiraju kardinalne nego kosokutne orijentacije. Osim toga, veća raznolikost orijentacija u vidnom prikazu izazvala je veću pristranost procjena prema kardinalnim orijentacijama, što su potvrdili i Wei i Stocker (2017). Nadalje, Pratte i sur. (2017) pokazali su da odgođeno dosjećanje orijentacije uz kontinuiranu procjenu rezultira većom preciznošću za kardinalne nego za kosokutne orijentacije, što implicira da razlike između prikazanih podražaja jesu bitan izvor varijabilnosti u dosjećanju iz vidnog radnog pamćenja.

Slični su rezultati dobiveni prilikom ispitivanja vidnog radnog pamćenja za boje. U paradigmi se odgođenog dosjećanja uz kontinuiranu procjenu boja ciljnog podražaja određuje nasumičnim odabirom iz kontinuiranog seta. Redovita je praksa u statističkoj analizi da se sekvence s podražajima različitih ciljnih boja grupiraju prilikom procjene preciznosti dosjećanja, pri čemu se implicitno pretpostavlja da preciznost ne ovisi o točnoj nijansi boje podražaja (npr. vidi Fougnie, Suchow i Alvarez, 2012). Bae, Olkkonen, Allred, Wilson i Flombaum (2014) testirali su tu pretpostavku te pokazali da preciznost dosjećanja sustavno varira ovisno o kvaliteti boje koja se pamti, i to na način da se sudionici preciznije dosjećaju prototipnih boja pojedine kategorije (npr. zelene u odnosu na cijan). Ključno, ovakvo je variranje preciznosti dosjećanja sustavno opaženo kod svih sudionika što govori kako se dio varijabiliteta dosjećanja može opisati karakteristikama podražaja.

\section{Karakteristike podražajnog konteksta - efekt privlačenja}

Osim karakteristika podražajnog materijala, u zadacima vidnog radnog pamćenja moguće je demonstrirati i utjecaj karakteristika konteksta. Točnije, prethodna su istraživanja sugerirala da sudionici pamte statističku reprezentaciju skupa podražaja te da je odgovor prilikom dosjećanja pristran prema prosječnoj vrijednosti svih zapamćenih podražaja (npr. prosječnoj orijentaciji) (Brady i Alvarez, 2011; Brady i Tenenbaum, 2013; Huang i Sekuler, 2010; Orhan i Jacobs, 2013). Primjerice, Brady i Alvarez (2011) pokazali su da upamćena veličina pojedinačnih elemenata u vidnom prikazu naginje ka prosječnoj veličini elemenata iste boje kada je boja elemenata istaknuto obilježje koje potpomaže njihovo grupiranje, a da naginje ka prosječnoj veličini svih elemenata u prikazu kada se utjecaj boje kao obilježja za 
grupiranje smanji. Iz tih su nalaza autori zaključili da se elementi u vidnom radnom pamćenju ne reprezentiraju neovisno jedan o drugome, već da se prilikom konstrukcije mentalnih reprezentacija pojedinačnih elemenata koriste statističke informacije o skupu kojega je taj pojedinačni element član. Sličan se efekt javlja već i u slučaju pamćenja samo dvije orijentacije, što dovodi do vrlo predvidljive distorzije dosjećanja i znači da će dosjećanje svake od njih biti sustavno pomaknuto u smjeru prosjeka, odnosno otklonjeno u smjeru druge orijentacije koja je zapamćena, ali je se sudionici u tom trenu ne trebaju dosjetiti. Ovaj je efekt u literaturi poznat kao efekt privlačenja.

Huang i Sekuler (2010) demonstrirali su ovaj efekt. Sudionicima su prikazivali po dva uzastopna Gaborova podražaja (za primjer Gaborova podražaja vidite Sliku 1.) te ih tražili da se dosjete prostorne frekvencije jednog od njih. Prije dosjećanja sudionicima je signalizirano na koji od dva podražaja trebaju usmjeriti pažnju (ciljni podražaj). Rezultati su pokazali da sudionici prilikom dosjećanja prostornu frekvenciju ciljnog podražaja sustavno približavaju prostornoj frekvenciji sporednog podražaja. Pritom, što je razlika u prostornim frekvencijama između ciljnog i sporednog podražaja bila veća, to je i pristranost bila izraženija. Slično tome, Nemes, Whitaker, Heron i McKeefry (2011) pokazali su da na dosjećanje prostorne frekvencije ciljnog podražaja utječe prostorna frekvencija maskirajućeg podražaja, koji se prezentira nakon ciljnog. Pri prilagođavanju frekvencije testnog podražaja (uzorka koji sudionik prilagođava/uspoređuje sa sadržajem u radnom pamćenju) onoj upamćenoj javila se pristranost u smjeru maskirajućeg podražaja, koja je rasla porastom razlike između frekvencija ciljnog i maskirajućeg podražaja. Međutim, kad je ta razlika premašila određeni iznos, preciznost se počela povećavati. Iste su rezultate dobili i pri ispitivanju dosjećanja boja (Nemes, Parry, Whitaker i McKeefry, 2012).

\section{Metaznanje}

Neka istraživanja upućuju na to da sudionici imaju razvijeno metaznanje o tome koje su podražaje najbolje zapamtili. Primjerice, u istraživanju Suchowa, Fougniea i Alvareza (2017) u zadatku dosjećanja boje nasumično odabranog kruga ili boje kruga koji su, po vlastitoj procjeni, najbolje zapamtili, učinak sudionika bio je bolji kad su mogli sami birati kojeg će se kruga dosjetiti. Kad im je eksplicitno zadano da se usmjere na podražaj koji su najbolje ili najlošije zapamtili, preciznost dosjećanja bila je viša u prvom slučaju nego u drugom. Osim toga, kad su mogli sami birati kojeg će se podražaja dosjetiti, postizali su bolji učinak nego kad je podražaj odabran nasumce. Ključno, porastom broja podražaja za pamćenje dolazilo je do pada u preciznosti dosjećanja, što implicira da su se prvo dosjećali podražaja koje su najbolje zapamtili. U istraživanju Adam, Vogela i Awha (2017) sudionici su se trebali dosjećati svih elemenata u prikazu, i to samostalno odabranim redoslijedom, pri čemu su trebali naznačiti smatraju li da imaju bilo kakve informacije o podražaju kojega se trenutno dosjećaju ili ne. Rezultati su pokazali da preciznost dosjećanja 
elemenata unutar seta pada za svaki sljedeći element kojeg su se sudionici dosjetili. To implicira da su se sudionici prvo dosjećali elemenata koje su najbolje zapamtili, što govori da su imali pouzdano metaznanje o zapamćenim elementima.

\section{Pažnja}

Procesi pažnje imaju posebnu ulogu u području istraživanja vidnog radnog pamćenja. Tipično, istraživanja pokazuju da usmjeravanje pažnje na manji skup podražaja, od svih potrebnih za obavljanje zadatka, pospješuje uradak vezan uz taj manji skup podražaja (Munneke, Heslenfeld i Theeuwes, 2010; Schmidt, Vogel, Woodman i Luck, 2002; Theeuwes, Kramer i Irwin, 2011). Najčešće su upotrebljavane paradigme za ispitivanje procesa pažnje $u$ vidnom radnom pamćenju paradigme signaliziranja unaprijed i signaliziranja unatrag. Signal unaprijed koristi se kako bi se pažnja sudionika usmjerila na konkretan podražaj, i to prije nadolazećeg skupa podražaja za pamćenje. Signal unatrag koristi se kako bi se fokus pažnje usmjerio na neki od prethodno zapamćenih podražaja, te se prikazuje nakon nestanka senzornog podraživanja, a prije dosjećanja.

O pozitivnom učinku signaliziranja na pamćenje govore rezultati istraživanja koje su proveli Griffin i Nobre (2003). Oni su kao podražajni materijal koristili četiri istovremeno prikazana obojena križića, a zadatak je sudionika bio reći je li se testni križić nalazio među četiri ranije prikazana ili nije. Sudionicima je prije i poslije prikazivanja podražajnog materijala prikazan signal u tri različite situacije: (i) signaliziranje unaprijed, gdje je signal prikazan prije podražajnog materijala bio informativan, a signal prikazan poslije podražajnog materijala neinformativan, (ii) signaliziranje unatrag, gdje je vrijedilo obrnuto od prethodnog, te (iii) neutralno signaliziranje, gdje nijedan signal nije bio informativan. Rezultati su pokazali da je točnost dosjećanja bila bolja kad je signal prikazan unaprijed ili unatrag nego kad je prikazan neutralan signal. Između situacija sa signaliziranjem unaprijed i unatrag nije pronađena statistički značajna razlika, čime su autori pokazali da se orijentiranje selektivne pažnje na unutarnje reprezentacije bitno ne razlikuje od orijentiranja na vanjske podražaje.

Njihove su nalaze proširili Dubé, Zhou, Kahana i Sekuler (2014). Sudionicima su prezentirali jedan ili dva Gaborova podražaja te im davali različite vrste signala s ciljem usmjeravanja pažnje na jedan ili oba prikazana podražaja. Nakon prikazivanja podražaja za pamćenje prikazan je testni Gaborov podražaj, a zadatak je sudionika bio odrediti je li testni podražaj jednak nekom od podražaja za pamćenje (odluka $\mathrm{da} / \mathrm{ne}$ ). Rezultati njihova istraživanja pokazuju da je u slučaju prikazivanja signala koji upućuje na to da treba pamtiti oba podražaja povećana stopa lažnih uzbuna za testne podražaje čije su prostorne frekvencije blizu prosječne prostorne frekvencije podražaja za pamćenje, u usporedbi sa situacijom u kojoj je signalizirano pamćenje samo jednog podražaja. To implicira da signaliziranje može uspješno preusmjeriti pažnju na jedan od podražaja te time smanjiti efekt privlačenja. Osim toga, u 
istraživanju Huanga i Sekulera (2010) pokazalo se da je efekt privlačenja za prostorne frekvencije manji u slučaju signaliziranja unaprijed nego u slučaju signaliziranja unatrag.

\section{Cilj istraživanja}

Potaknuti prethodnim istraživanjima željeli smo provjeriti robusnost efekta privlačenja. Ispitivanje razmjera raznih pristranosti u perceptivnim odlukama može pružiti informacije važne za teorijsku analizu i opis perceptivnog sustava. Ovisno o tome na koje se manipulacije određeni kontekstualni efekt pokazuje otpornim ili neotpornim, rezultati istraživanja mogu uputiti na specifičnu razinu hijerarhije procesiranja na kojoj efekt nastaje, a time i na moguće neuralne supstrate u njegovoj podlozi (Fritsche i de Lange, 2019). Primjerice, neki kontekstualni efekti očituju se već u samoj pojavnosti podražaja (Webster, 2015), dok se neki javljaju kasnije, na post-perceptivnim razinama procesiranja (Firestone i Scholl, 2016; Huang i Sekuler, 2010), što određuje koje informacije organizam ima na raspolaganju u određenom trenutku. Kada bi se efekt pokazao otpornim na manipulacije koje djeluju na kasnije stadije procesiranja, mjesto u toj hijerarhiji gdje efekt nastaje trebali bismo tražiti na nekoj nižoj razini. U ovom smo radu željeli provjeriti ostaje li efekt privlačenja prisutan i kada sudionici imaju priliku samostalno odabrati podražaj kojeg se žele dosjetiti te kada je usmjeravanjem pažnje prednost dana jednom od podražaja za pamćenje. Nadalje, željeli smo provjeriti ostaje li efekt privlačenja prisutan kod preostalih podražaja pohranjenih u vidnom radnom pamćenju, konkretno, podražaja koje sudionici nisu odabrali za prvo dosjećanje, te onih kojima nije dana prednost putem usmjeravanja pažnje. Gledano s metodološkog aspekta, uvid u otpornost efekta privlačenja na spomenute manipulacije važan je za istraživanja koja koriste prikaze sličnih podražajnih materijala u sličnim eksperimentalnim uvjetima, jer bi omogućio precizniju eksperimentalnu kontrolu te valjanije testiranje hipoteza o mehanizmima radnog pamćenja.

\section{Metoda}

U svrhu postizanja postavljenih ciljeva provedena su četiri eksperimenta $\mathrm{u}$ kojima su sudionici pamtili dva podražaja, a zatim se dosjećali oba. Pritom je redoslijed dosjećanja bio odabran slučajno (eksperiment 1) ili samostalno (eksperiment 2) te signaliziran prije (eksperiment 3) ili nakon (eksperiment 4) prikaza podražaja za pamćenje.

\section{Sudionici}

U istraživanju je sudjelovalo trideset i troje sudionika ( $\check{z}=21$, dob 19-33). Svi su sudionici izvijestili kako imaju zdrav ili adekvatno korigiran vid. U eksperimentu 
1 i 2 sudjelovalo je 10 sudionika ( $\check{z}=7$ ). Kako je pojedinačno trajanje prvih dvaju eksperimenata bilo između 20 i 25 minuta, isti su sudionici sudjelovali u oba eksperimenta. Redoslijed je dvaju eksperimenata za sudionike naizmjence rotiran. U eksperimentu 3 sudjelovalo je 10 novih sudionika $(\check{z}=4)$, dok je za posljednji eksperiment regrutirano novih 13 sudionika $(\check{z}=10)$.

\section{Podražajni materijal}

Kao podražajni su materijal u svim eksperimentima korišteni Gaborovi podražaji visokog kontrasta, prikazani na sivoj pozadini zaslona računala (Slika 1.). Orijentacija podražaja generirana je po slučaju za svaku sekvencu. Podražaji (njihovo središte) prikazivani su na nasumičnim lokacijama, ekvidistantno raspoređenima po zamišljenoj kružnici radijusa $6^{\circ}$ vidnog polja, s centrom u središtu zaslona. Podražaji su prikazani na 19 inčnom LCD monitoru uz osvježavanje od 75 $\mathrm{Hz}$. Sudionici su promatrali podražaje s udaljenosti od otprilike $70 \mathrm{~cm}$. Prikazivanje podražaja i prikupljanje podataka kontrolirano je pomoću skripte napisane u Psychtoolbox (Pelli, 1997) koristeći program Matlab (The Mathworks Inc.).

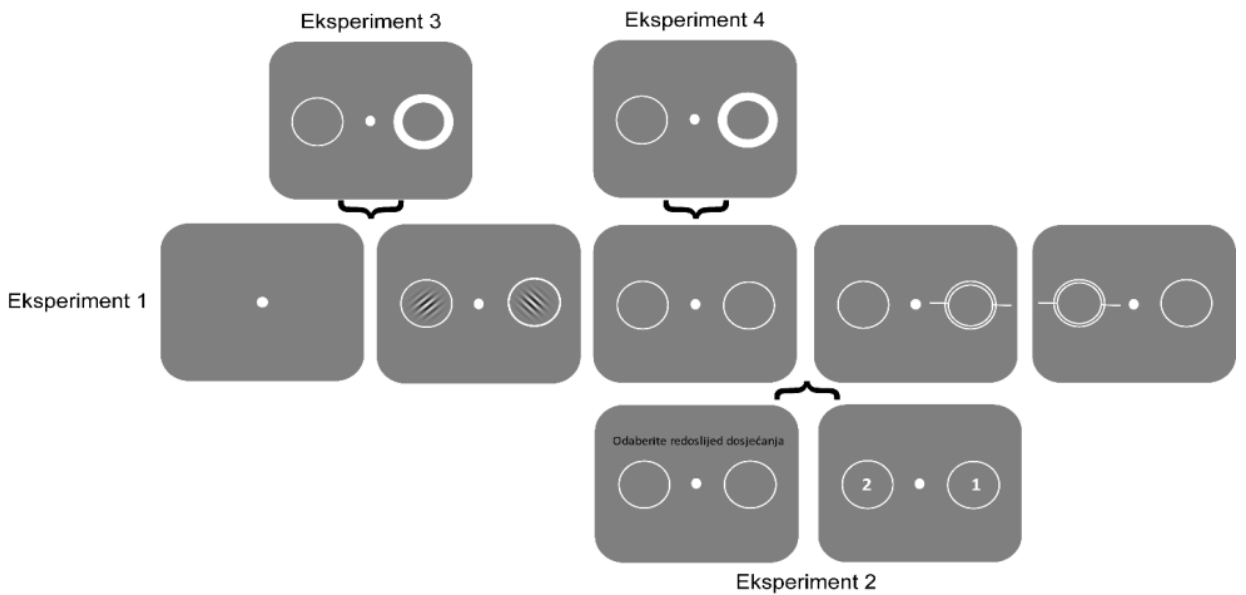

Slika 1. Shematski prikaz eksperimentalnih zadataka korištenih u četiri opisana eksperimenta (sivi pravokutnici simboliziraju prikaz na zaslonu računala). Ovaj je prikaz samo za situaciju kada su se prikazivala dva podražaja. Postupak u eksperimentu 1 uzet je kao paradigmatski, a varijacije ostalih označene su iznad (eksperiment 3 i 4) te ispod (eksperiment 2) toga osnovnog prikaza.

\section{Postupak}

Prije početka eksperimenta sudionici su pročitali i potpisali pristanak za sudjelovanje $u$ istraživanju, nakon čega im je dana uputa o zadatku koji će rješavati. Na početku eksperimenta svaki je sudionik prošao kroz kratku vježbu (12 sekvenci) 
kako bi se upoznao sa zadatkom. Postupak svakoga pojedinog eksperimenta opisan je u nastavku.

\section{Eksperiment 1}

Sudionicima je na početku svake sekvence prikazan sivi fiksacijski kružić na sredini zaslona (izostavljen sa Slike 1.). Nakon prolaska određenog vremenskog intervala, čije je trajanje odabrano po slučaju iz raspona od 1 do 2 sekunde, kružić je promijenio boju u bijelu, što je bio znak da uskoro slijedi prikaz podražaja (prvi zaslon na Slici 1., Eksperiment 1). Vrijeme od pojave bijelog kružića do pojave podražaja varirano je u rasponu od 300 do $700 \mathrm{~ms}$. Slučajan odabir vremena pripreme korišten je kako bi se onemogućilo strateško uključivanje procesa pažnje. Nakon toga slijedila je prezentacija podražaja (drugi zaslon na Slici 1.) različitih prostornih orijentacija pruga. Svaka je podražajna sekvenca mogla imati prikaz s 2, 3 ili 4 podražaja za pamćenje. $\mathrm{U}$ ovom ćemo radu prikazati samo dijelove eksperimenata i opažene rezultate kada su sudionici pamtili dva podražaja.

Trajanje prikaza podražaja bilo je $150 \mathrm{~ms}$ ili $750 \mathrm{~ms}$ (odabrano po slučaju). Nakon podražaja uslijedio je prikaz zaslona samo s fiksacijskim kružićem i oznakama lokacija (kružnicama) gdje su podražaji bili prikazani (treći zaslon na Slici 1.). Taj je prikaz trajao $2000 \mathrm{~ms}$ i predstavlja fazu zadržavanja. Nakon toga slijedio je prikaz na kojem su sudionici trebali davati svoje odgovore (zasloni 4 i 5 na Slici 1.). Sudionicima je u uputi rečeno da trebaju zapamtiti prostornu orijentaciju prezentiranih podražaja. Redoslijed dosjećanja podražaja odabran je po slučaju. Sudionici su se trebali dosjetiti orijentacije onog podražaja koji je bio označen dodatnom, manjom kružnicom unutar šire, te linijama sa strane kružnice. U primjeru ilustriranom na Slici 1. sudionici su se prvo trebali dosjetiti prostorne orijentacije desnog podražaja, a zatim lijevog. Linije izvan kružnice pomicale su se pri pomicanju miša te označavale prostornu orijentaciju koje su se sudionici pokušavali dosjetiti.

Nakon što su prilagodili orijentaciju linije onoj zapamćenoj, sudionici su potvrdili svoj odgovor klikom miša. Nakon davanja prvog odgovora uslijedilo je dosjećanje ostalih prikazanih podražaja. Vrijeme davanja odgovora nije bilo ograničeno. Sudionici su ukupno prolazili kroz 240 sekvenci podijeljenih u tri bloka, između kojih su mogli uzeti stanku.

\section{Eksperiment 2}

U ovom je eksperimentu korišten isti zadatak kao i u prvom, uz nekoliko izmjena. Sudionicima je prije početka eksperimenta uputom rečeno da će sami odabirati redoslijed dosjećanja orijentacija podražaja. Nakon prikaza podražaja za pamćenje i faze zadržavanja sudionicima je prikazan zaslon s natpisom 'Odaberite redoslijed dosjećanja' (vidi Sliku 1.). Nakon odabira redoslijeda klikom miša kratko 
je prikazan $(500 \mathrm{~ms})$ podsjetnik redoslijeda dosjećanja (redni broj dosjećanja na mjestu podražaja, vidi Sliku 1.). Ostatak je zadatka bio identičan onomu u eksperimentu 1, uključujući vremena trajanja pojedinih prikaza. Vrijeme odabira redoslijeda dosjećanja i davanja odgovora nije bilo ograničeno. Sudionici su ukupno prolazili kroz 240 sekvenci podijeljenih u tri bloka, između kojih su mogli uzeti stanku.

\section{Eksperiment 3}

Za provedbu je ovog eksperimenta korištena paradigma signala unaprijed dok je ostatak zadatka bio identičan onom iz eksperimenta 1. U skladu s paradigmom, na početku svake sekvence, odnosno nakon bijeloga fiksacijskog kružića, a prije podražaja za pamćenje, sudionicima su prikazane oznake podražaja, pri čemu je jedna, po slučaju odabrana, imala zadebljanu bijelu kružnicu (vidi Sliku 1., Eksperiment 3). Sudionicima je uputom rečeno da će se orijentacije Gaborova podražaja prikazane na toj lokaciji najvjerojatnije morati dosjetiti prve. Nakon toga su sudionicima prikazani podražaji $\mathrm{u}$ trajanju od $750 \mathrm{~ms}$, a zatim zaslon $\mathrm{s}$ fiksacijskim kružićem i oznakama lokacija (2000 ms), čemu je slijedilo dosjećanje. U 75\% sekvenci od sudionika se tražilo da se prvo dosjete orijentacije prikazane na prethodno signaliziranoj lokaciji, dok ih se u preostalim sekvencama tražilo da se prvo dosjete orijentacije prikazane na nesignaliziranoj lokaciji. Sudionici su prošli kroz ukupno 354 sekvence podijeljene u šest blokova, između kojih su mogli uzeti stanku.

\section{Eksperiment 4}

Posljednji je eksperiment po svim karakteristikama bio jednak eksperimentu 3, s razlikom da je signal koji naznačuje za koji je podražaj najvjerojatnije da će se prvi ispitivati prikazan nakon nestanka podražaja za pamćenje. Jednu sekundu nakon nestanka podražaja za pamćenje sudionicima je nakratko prikazan signal unatrag (podebljana kružnica trajanja $250 \mathrm{~ms}$ ) nakon čega je uslijedio drugi dio faze zadržavanja $(750 \mathrm{~ms})$. Ostatak sekvence, uključujući vremena prezentacije i dosjećanje, bio je jednak onom opisanom u eksperimentu 3. 


\section{Rezultati}

Orijentacije su analizirane $\mathrm{i}$ ovdje prikazane s obzirom na cirkularni prostor, $\mathrm{tj}$. jedinstvene orijentacije $[-\pi / 2, \pi / 2)$ radijana transformirane su u raspon $[-\pi, \pi)$ radijana. Prvi korak $\mathrm{u}$ analizi rezultata bila je provjera točnosti uratka sudionika $\mathrm{u}$ eksperimentima. Za svaki je odgovor izračunata pogreška dosjećanja kao razlika prikazane orijentacije i orijentacije koju je ispitanik ponudio kao odgovor prilikom dosjećanja. Kao zavisnu varijablu uratka koristili smo prosječno apsolutno odstupanje izračunato iz distribucije pogrešaka dosjećanja, izraženo u radijanima.

Sudionicima su u prva dva eksperimenta podražaji prikazivani uz kratke (150 $\mathrm{ms})$ i duge $(750 \mathrm{~ms})$ ekspozicije. Kako su za pamćenje malog broja podražaja za potpuno kodiranje sudionicima dovoljne kraće ekspozicije, provjerili smo razlike u uratku s obzirom na vrijeme kodiranja. Prosječna apsolutna odstupanja nisu se razlikovala između kratkog i dugog vremena kodiranja. Konkretno, u eksperimentu 1 nije pronađena statistički značajna razlika ni za davanja prvog odgovora $(t(9)=$ $0.24, p=.81)$ ni za davanja drugog odgovora $(t(9)=0.98, p=.36)$, baš kao ni u eksperimentu 2 (davanje prvog odgovora $(t(9)=0.63, p=.54$ ); davanja drugog odgovora $(t(9)=1.12, p=.29)$. Stoga smo uradak u prva dva eksperimenta odlučili prikazati ne uzimajući u obzir vrijeme kodiranja.

$\mathrm{U}$ drugom smo koraku provjerili razlike u uratku s obzirom na redni broj dosjećanja. Prosječna apsolutna odstupanja dobivena u eksperimentima prikazana su na Slici 2. Testiranjem nije pronađena statistički značajna razlika u dosjećanju u eksperimentu $1(t(9)=0.67, p=.52)$ ni u eksperimentu $2(t(9)=1.33, p=.22)$. $\mathrm{S}$ obzirom na to da je cilj eksperimenata 3 i 4 bio ispitati utjecaj signaliziranja na efekt privlačenja, $u$ analizi smo se usmjerili samo na prediktivne sekvence, tj. samo one na kojima su se sudionici prvo dosjećali signaliziranog podražaja ( $75 \%$ svih sekvenci). Nije pronađena statistički značajna razlika između prvog i drugog dosjećanja ni u eksperimentu $3(t(9)=2.1, p=.07)$ ni u eksperimentu $4(t(12)=0.5, p=.63)$.

Treći je korak bilo ispitivanje pogrešaka dosjećanja ovisno o sličnosti dvaju prikazanih podražaja. Ako dosjećanje podražaja ovisi samo o njegovoj zapamćenoj orijentaciji, tada pogreške dosjećanja ne bi trebale pokazivati nikakvo sustavno variranje ovisno o sličnosti dviju prikazanih orijentacija. S druge strane, ako dosjećanje jednog podražaja ovisi o orijentaciji drugog podražaja, tada bi pogreške dosjećanja jednog podražaja trebale pokazati pristranost u smjeru orijentacije onog drugog podražaja, odnosno efekt privlačenja.

Kako bismo provjerili postojanje ovog efekta prilikom dosjećanja orijentacije, najprije smo operacionalizirali sličnost dvaju prikazanih podražaja u pojedinoj sekvenci. Za svako smo dosjećanje prvo izračunali razliku između orijentacija prikazanih podražaja: za prvi je odgovor tražena orijentacija oduzeta od orijentacije koje su se sudionici trebali dosjetiti kod drugog dosjećanja; za drugi je odgovor tražena orijentacija oduzeta od orijentacije koje su se sudionici trebali dosjetiti kod prvog dosjećanja. Te su razlike na skali radijana mogle poprimiti vrijednosti u 


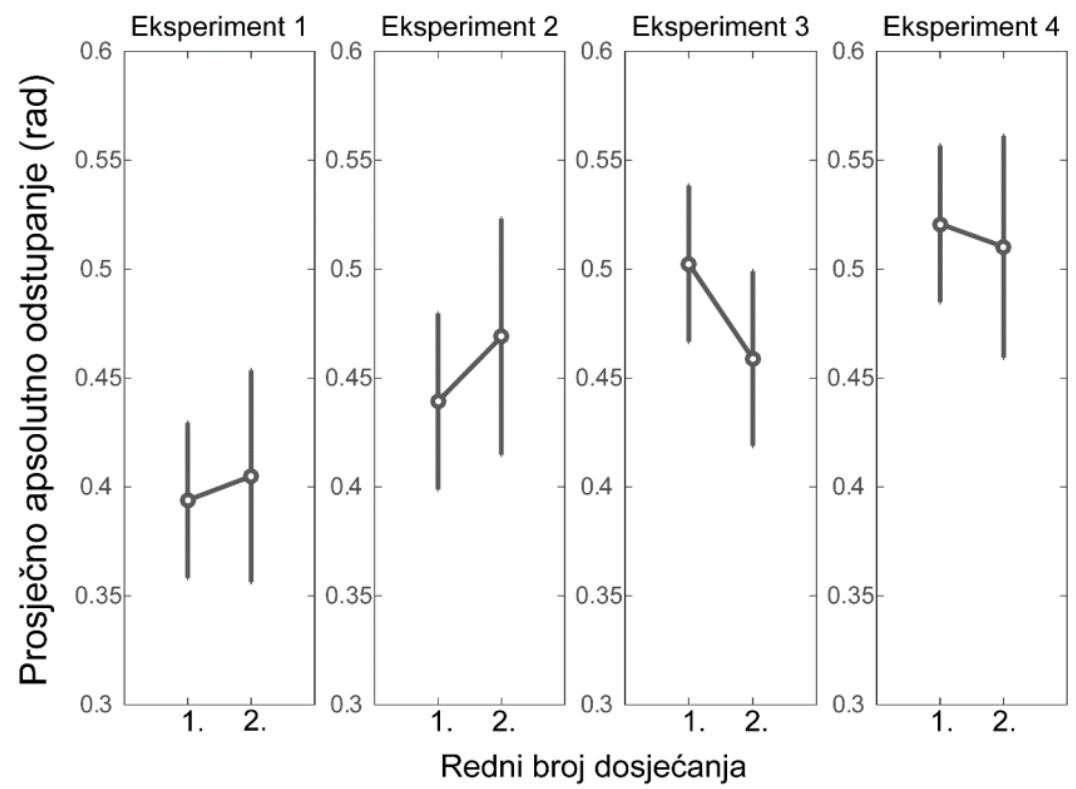

Slika 2. Pogreške dosjećanja izražene kao prosječna apsolutna odstupanja $\left(M \pm S D_{M}\right)$ u radijanima za dva dosjećanja u četiri provedena eksperimenta.

rasponu od $-\pi$, preko 0 (ako su podražaji imali identičnu orijentaciju), pa do $+\pi$. S obzirom na provedenu transformaciju jedinstvenih vrijednosti u kružni prostor, kod vrijednosti razlike od $\pm \pi$ dva su prikazana podražaja imala ortogonalne orijentacije. Ovakvo dobivene razlike dviju orijentacija potom smo grupirali u 13 razreda, zasebno za svaki od dva prikazana podražaja. Te su razlike prikazane na apscisama grafova na Slici 3. Ovdje je važno napomenuti da je odabir broja razreda proizvoljan i da ne postoji jasan kriterij oko broja razreda koji bismo ovdje trebali odabrati. Za svaki je od tih razreda izračunata pogreška dosjećanja. Efekt privlačenja očituje se u sinusoidnoj krivulji koja opisuje odnos između sličnosti dvaju prikazanih podražaja i pogreške dosjećanja. Pogreške dosjećanja (razlika između prikazane orijentacije i procijenjene orijentacije) trebale bi pokazati najveću pristranost kada su dva podražaja bila umjereno različita (između $0 \mathrm{i} \pm \pi / 2$ ). Na Slici 3. prikazani su odnosi sličnosti dvaju upamćenih podražaja i pogrešaka dosjećanja za četiri eksperimenta, i to zasebno za prvi i drugi odgovor. Vrijednosti prikazane na Slici 3. odgovaraju cirkularnim aritmetičkim sredinama opaženih pogrešaka dosjećanja izračunatima na temelju agregiranih reakcija svih ispitanika, za pojedini razred. 

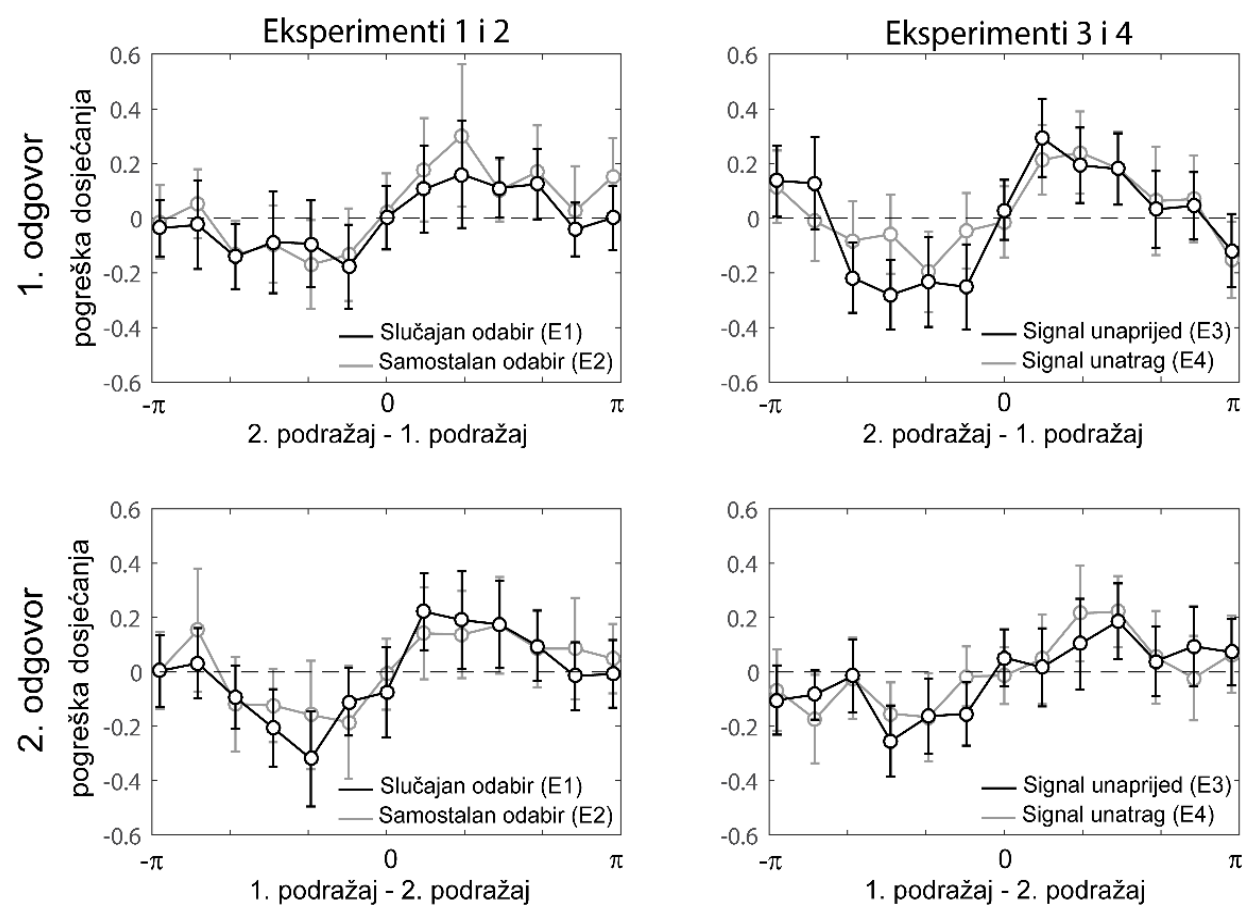

Slika 3. Pogreška dosjećanja ovisno o sličnosti dvaju zapamćenih podražaja. U gornjim su prikazima pogreške dosjećanja prilikom davanja prvog odgovora, a u donjim pogreška kod davanja drugog odgovora. Prikazane vrijednosti odgovaraju cirkularnoj aritmetičkoj sredini pogreške ( $\pm 95 \%$ interval pouzdanosti) u pojedinom razredu. Pogreške dosjećanja izračunate su kao razlika orijentacije 2. i 1. podražaja koda prvog odgovora, odnosno razlike orijentacije 1. i 2. podražaja kod drugog odgovora. Vrijednosti su izražene su u radijanima. Isprekidana vodoravna crta označava očekivanu pogrešku dosjećanja uz izostanak efekta privlačenja.

U eksperimentu 1, uz slučajan redoslijed dosjećanja, kod obaju je odgovora pronađen sinusoidan odnos sličnosti podražaja i prosječne pogreške dosjećanja (Slika 3., Eksperimenti 1 i 2, crna boja). Kako bismo provjerili razlikuju li se ta odstupanja od nulte vrijednosti, izračunali smo prosječne apsolutne magnitude pogrešaka te testirali razlikuju li se te vrijednosti od 0 . Efekt je bio nešto slabije izražen kod davanja prvog odgovora, uz prosječnu apsolutnu magnitudu odstupanja od $M_{1 .}=0.085$ radijana, odnosno nešto snažniji kod drugog dosjećanja uz prosječnu apsolutnu magnitudu $M_{2}=0.119$. Ova se magnituda razlikovala od nule i kod davanja prvog $(t(12)=5.21, p<.001$, Cohenov $d=1.4)$ i kod davanja drugog odgovora $(t(12)=4.4, p<.001$, Cohenov $d=1.22)$. Ovi testovi pokazuju da su opažena odstupanja sustavno veća od onih koje bismo očekivali kada ne bi postojala pristranost odgovaranja. Konačno, statistički gledano najstroža je provjera pristranosti dosjećanja analiza odstupanja u pojedinom razredu. Intervali pouzdanosti (95\%) za magnitude u pojedinom razredu kod davanja prvog odgovora 
ili granično obuhvaćaju vrijednost 0 ili se intervalom nalaze iznad (kod pozitivnih razlika), odnosno ispod (kod negativnih razlika) vrijednosti 0 . Za drugo se dosjećanje intervali pouzdanosti za pozitivne razlike nalaze dominantno iznad, a za negativne razlike dominantno ispod nule. Ukupno gledano, u eksperimentu 1 pronađen je jasan nalaz o postojanju efekta privlačenja kod dosjećanja orijentacija prikupljenih paradigmom slučajnog redoslijeda dosjećanja.

U eksperimentu 2 sudionici su samostalno odabirali redoslijed dosjećanja, a efekt privlačenja ostao je prisutan i veličinom sličan onom opaženom u eksperimentu 1 (Slika 3., Eksperimenti 1 i 2, siva boja). Prepoznatljiv sinusoidan trend opažen je kod davanja oba odgovora, tako da su za pozitivne razlike dva prikazana podražaja pogreške imale pozitivnu pristranost, dok su za negativne razlike pogreške imale negativnu pristranost. Prosječne apsolutne magnitude za dva odgovora bile su vrlo slične veličinom, specifično $M_{1 .}=0.12$ i $M_{2}=0.11$. Test razlike tih magnituda pokazao je kako se one razlikuju od 0 i kod prvog $(t(12)=5.35, p<.001$, Cohenov $d=1.49)$ i kod drugog odgovora $(t(12)=6.68, p<.001$, Cohenov $d=1.85)$. Kao i u slučaju eksperimenta 1 , ovi testovi pokazali su kako se opažena odstupanja sustavno razlikuju od 0. Ponovno, najstroži test prisutnosti efekta privlačenja jest provjera obuhvaća li 95-postotni interval prosječne pogreške unutar pojedinog razreda vrijednost 0 . Kod prvog odgovora, ovi intervali većinom granično obuhvaćaju vrijednost 0 , i to kod pozitivnih i negativnih razlika dvaju prikazanih podražaja, uz barem jedan razred čiji se cijeli interval kod pozitivnih odnosno negativnih razlika nalazi iznad odnosno ispod vrijednosti 0 . Kod davanja drugog odgovora niti jedan interval se $u$ cijelosti ne nalazi iznad odnosno ispod vrijednosti 0 , međutim, trend $u$ kojem intervali dominantno granično zahvaćaju vrijednost 0 opažen je i ovdje. Zaključno, u eksperimentu 2, korištenjem paradigme samostalnog odabira redoslijeda dosjećanja pronađen je prepoznatljiv obrazac variranja pogrešaka ovisno o sličnosti dva prikazana podražaja pri čemu su se apsolutne veličine tih odstupanja kod davanja oba odgovora razlikovale od 0 .

U eksperimentu 3 korišten je signal unaprijed koji je sudionicima pokazao kojeg će se od dva podražaja morati dosjetiti prvog (Slika 3., Eksperimenti 3 i 4, crna boja). Ponovno, efekt privlačenja pronađen je pri davanju obaju odgovora. Pritom, efekt je bio nešto snažniji za prvo $\left(M_{1}=0.165\right)$ u odnosu na drugo dosjećanje $\left(M_{2 .}=0.103\right)$. Apsolutna veličina odstupanja razlikovala se od 0 i kod prvog dosjećanja $(t(12)=$ $6.49, p<.001$, Cohenov $d=1.8)$ i kod drugog dosjećanja $(t(12)=5.3, p<.001$, Cohenov $d=1.47$ ). Analiza pristranosti u pojedinom razredu pokazala je vrlo uvjerljive nalaze u prilog postojanja pristranosti tako da su intervali pogrešaka kod pozitivnih razlika dva podražaja dominantno bili iznad vrijednosti 0 , a za negativne razlike ispod vrijednosti 0 . Kod drugog dosjećanja pojedinačni intervali su se manje konzistentno razlikovali od 0 iako je i ovdje postojala jasna pristranost u skladu s očekivanjima. Signaliziranje podražaja kojeg će se sudionici morati dosjetiti prvog nije smanjilo pristranost prilikom dosjećanja tog podražaja. Štoviše, veličina pristranosti ukazuje kako se ta pristranost povećala. 
U eksperimentu 4 sudionicima je signalizirano kojeg će se podražaja prvo dosjećati, no tek nakon što je nestalo senzorno podraživanje (Slika 3., Eksperimenti 3 i 4 , siva boja). Kao i u eksperimentu 3 signal je sudionike trebao dodatno usmjeriti na jedan od dva podražaja, no ovog puta nakon što su oba podražaja kodirana. U skladu s nalazima u prethodna tri eksperimenta, i ovdje je pronađena pristranost dosjećanja. Na Slici 3. vidljiv je očekivan odnos sličnosti dvaju prikazanih podražaja i pogreške dosjećanja. Magnitude pristranosti za prvo i drugo dosjećanje bile su podjednake $\left(M_{1 .}=0.111, M_{2}=0.095\right)$. Usporedba je ovih apsolutnih odstupanja pokazala značajnu razliku od 0 i kod prvog dosjećanja $(t(12)=5.15, p<.001$, Cohenov $d=1.43)$ i kod drugog dosjećanja $(t(12)=4.36, p<.001$, Cohenov $d=$ 1.21). Naposljetku, u skladu je s rezultatima opaženima u prethodna tri eksperimenta analiza pojedinačnih intervala pokazala kako intervali pretežito tek granično obuhvaćaju vrijednosti 0 , uz značajna odstupanja od nulte pogreške dosjećanja za razrede u rasponu između $0 \mathrm{i} \pm \pi / 2$. I u ovom je posljednjem eksperimentu efekt privlačenja ostao usporediv s onim opaženim u eksperimentu 1.

\section{Rasprava}

U istraživanjima vidnoga radnog pamćenja i naročito vidne percepcije dobro je potvrđen nalaz da sudionici vidne podražaje kodiraju ovisno o cjelokupnom vidnom prikazu. Konkretno, kvaliteta vidnog podražaja, poput boje i orijentacije, pamti se sustavno sličnijom preostalim podražajima. Nadalje, istraživanja su pokazala kako sudionici pamte podražaje sustavno sličnima čak i nevažnim podražajima poput distraktora (Rademaker, Bloem, De Weerd i Sack, 2015), što je poznato kao efekt privlačenja. U ovom smo radu željeli provjeriti otpornost ovog efekta. Istraživanja vidnoga radnog pamćenja predložila su brojne odrednice preciznosti pamćenja te uspješno demonstrirala kako vidno radno pamćenje može fleksibilno distribuirati dostupne resurse (Ma i sur., 2014). Fokus je tih istraživanja načelno usmjeren na ispitivanje u kojoj je mjeri raspodjela resursa pod voljnom kontrolom i na koji se način pridavanje više resursa jednom podražaju odražava na pamćenje tog podražaja, ali i preostalih podražaja važnih za zadatak.

U ovom smo se istraživanju koristili provjerenim metodama manipuliranja preciznosti reprezentacija u vidnom radnom pamćenju, no naš fokus pritom nije bio na opažanju razlika u preciznosti, već na modulaciji efekta privlačenja. Sudionici su kroz četiri eksperimenta pamtili dva jednostavna podražaja i u svakoj se sekvenci dosjećali obaju. U eksperimentu 1 korištena je tipična paradigma ispitivanja vidnog radnog pamćenja u kojoj se od sudionika traži da se dosjete zapamćenih podražaja slučajnim redoslijedom. Nalazi ovog eksperimenta pokazali su očekivani efekt privlačenja. Sudionici su kod prvog dosjećanja davali odgovore koji su bili sustavno pomaknuti u smjeru orijentacije drugog podražaja, dok su kod drugog dosjećanja sustavno reproducirali orijentacije slične orijentaciji podražaja kojeg su se prethodno 
dosjećali. U sljedeća tri eksperimenta smo eksperimentalnom manipulacijom pokušali smanjiti ovaj efekt.

U eksperimentu 2 sudionici su samostalno odabirali redoslijed dosjećanja. Prethodna su istraživanja demonstrirala kako sudionici, kada im se pruži prilika, za dosjećanje prvo odabiru podražaj koji su zapamtili najbolje (Adam i sur., 2017; Suchow i sur., 2017). Naši su rezultati pokazali da samostalan odabir redoslijeda dosjećanja nije umanjio efekt privlačenja. Konkretno, kod prvog dosjećanja, za koje pretpostavljamo da su sudionici odabirali podražaj koji su procijenili bolje kodiranim, reproducirana je orijentacija bila sustavno pomaknuta u smjeru orijentacije drugog prikazanog podražaja. Veličina te pristranosti bila je usporediva s onom opaženom kod dosjećanja drugog podražaja. Ovaj je eksperiment pokazao kako efekt privlačenja nije specifičan samo za zadatke sa slučajnim odabirom redoslijeda dosjećanja. Štoviše, čak i kada su sudionici tijekom faze zadržavanja imali priliku pripremiti se na odabir jednog od dva podražaja za dosjećanje, efekt privlačenja ostao je prisutan kod oba dosjećanja.

U eksperimentima 3 i 4 manipulirali smo fokusom pažnje tako što smo sudionicima prije odnosno nakon prezentacije podražaja za pamćenje signalizirali kojeg će se podražaja morati dosjetiti prvog. Dubé i sur. (2014) te Huang i Sekuler (2010) proučavali su ovakve manipulacije te pokazali da signaliziranje može uspješno umanjiti efekt privlačenja ako se signal daje unaprijed, ali ne i ako se daje unatrag. Rezultati našeg istraživanja pokazali su da ni u situaciji signaliziranja unaprijed ni u situaciji signaliziranja unatrag ne dolazi do smanjenja efekta privlačenja.

To se potencijalno može objasniti nekim metodološki važnim razlikama između našeg i gore spomenutih istraživanja. Za početak, oni su podražaje prikazivali sekvencijalno, a mi smo ih prikazivali istovremeno. Sljedeća je bitna metodološka razlika bila ta da su se sudionici u njihovu istraživanju trebali dosjetiti samo jednoga signaliziranog, od dva prikazana podražaja, dok je u našem istraživanju signal sudionike informirao o redoslijedu dosjećanja, ali su se oni u svakom slučaju trebali dosjetiti obaju prikazanih podražaja. U situaciji dosjećanja jednog podražaja, i naročito kod sekvencijalnog prikazivanja, signaliziranje unaprijed omogućava zanemarivanje nesignaliziranog podražaja. Alternativna interpretacija nalaza Huanga i Sekulera (2010) jest da su sudionici zanemarivali nesignalizirani podražaj, a ne da je sam proces usmjeravanja pažnje doveo do opaženog smanjivanja efekta.

Ovakav zadatak odabrali smo iz nekoliko razloga. Prije svega, kada ne bismo tražili dosjećanje obaju podražaja, sudionici bi se mogli koristiti strategijom pamćenja samo jednog podražaja u eksperimentima 2 i 3 , te izbacivanjem jednog podražaja nakon signala u eksperimentu 4 . U tom bi slučaju eventualno smanjivanje efekta privlačenja moglo biti uzrokovano time što drugi podražaj nije bio kodiran u vidnom radnom pamćenju. Nadalje, dosjećanje je obaju podražaja bilo nužno kako bismo provjerili prati li eventualno smanjenje efekta privlačenja kod prvog dosjećanja porast efekta privlačenja kod drugog dosjećanja. Osim toga, koristeći 
zadatak s dva podražaja željeli smo osigurati da sudionici vrlo precizno pamte oba podražaja te da se očekivani efekti ne mogu protumačiti kao posljedica neoptimalne dodjele resursa svakom podražaju.

Korištena manipulacija pažnje nije uspjela zaštititi podražaj od ostalih prisutnih informacija, tj. drugog prikazanog podražaja. Donekle iznenađujuće, efekt opažen prilikom drugog dosjećanja bio je usporediv s onim opaženim kod prvog dosjećanja. Ovaj je nalaz posebno zanimljiv jer pokazuje da je pohranjivanje podražaja dovedenog u fokus pažnje (signaliziranog) i podražaja izvan fokusa pažnje (nesignaliziranog) u jednakoj mjeri pod utjecajem preostalih informacija potrebnih za obavljanje zadatka.

Pri objašnjavanju vlastitih rezultata Huang i Sekuler (2010) upravo su selektivnoj pažnji pripisali zaštitno djelovanje koje je smanjilo utjecaj prostorne frekvencije irelevantnog podražaja na dosjećanje prostorne frekvencije ciljnog podražaja. Pri tome nisu predložili specifičnu lokaciju u hijerarhiji procesiranja vidnih informacija gdje bi selektivna pažnja intervenirala, naglašavajući da pažnja može djelovati i na nižim razinama hijerarhije (npr. Liu, Larsson i Carrasco, 2007; Martinez-Trujillo i Treue, 2004), ali i na postperceptivnim razinama. S druge strane, sâm efekt privlačenja pripisuju ranim stadijima procesiranja povezanima $\mathrm{s}$ kodiranjem u vidno radno pamćenje. Oslanjajući se na saznanja o integrativnoj funkciji vidnog sustava (npr. Brady i Alvarez, 2011), pretpostavljaju da su sudionici pohranjivali prosječne vrijednosti obilježja prikazanih podražaja, što je utjecalo na naknadno dosjećanje. Međutim, naši podaci ne idu u prilog ovom objašnjenju. Naime, kada bi ono bilo točno, odnos između razlike orijentacija dvaju prikazanih podražaja i magnitude pristranosti ne bi bio sinusoidalan, već pravocrtan, s najvećom pozitivnom magnitudom opaženom pri razlici od $+\pi$, a najvećom negativnom pri razlici od $-\pi$. Pri tim su vrijednostima orijentacije prikazanih podražaja ortogonalne, a njihov je prosjek tada najveći mogući. Kako se razlika u orijentacijama dvaju prikazanih podražaja smanjuje, tako se i njihov prosjek smanjuje. Kada bi sudionici svoju procjenu prilagođavali tom prosjeku, magnituda pristranosti bi bila najveća upravo kada je prosjek orijentacija najveći, a najmanja kada je on najmanji, tj. kada razlika orijentacija iznosi 0 .

Metodologija upotrijebljena u našem istraživanju upućuje na zaključak da mehanizmi u podlozi efekta privlačenja nisu podložni korekciji te da zaista jesu sastavni dio temeljnih procesa kodiranja vidnih podražaja. Ranija su psihofizička istraživanja vidnog radnog pamćenja pokazala da unutarnje reprezentacije nisu imune na interferenciju iz trenutnih perceptivnih procesa (Rademaker i sur., 2015), a pamćenje jednostavnoga vidnog obilježja, poput orijentacije, pokazalo se osjetljivim na distraktore koji sadrže konfliktne informacije s obzirom na isto to obilježje, ali ne i s obzirom na druga obilježja poput prostorne frekvencije (Magnussen i Greenlee, 1999). Ovakva međusobna izoliranost procesiranja temeljnih dimenzija vidnih podražaja upućuje na to da su elementi vidnog radnog pamćenja za jednostavna obilježja poput orijentacije reprezentirani u nižim razinama 
hijerarhije vidnog sustava (D'Esposito i Postle, 2015; Ma i sur., 2014; Magnussen, 2000; Magnussen i Greenlee, 1999). Interakcije između unutarnjih reprezentacija u radnom pamćenju, poput efekta privlačenja, uvelike ovise o relativnoj udaljenosti između vrijednosti obilježja pojedinih podražaja (Rademaker i sur., 2015). S obzirom na to jedan teorijski okvir predlaže da su elementi radnog pamćenja za jednostavna obilježja pohranjeni u modulima vidne kore velikog mozga specijaliziranima za procesiranje pojedinih obilježja vidnih podražaja, te da su inhibitorne interakcije između tih modula odgovorne za opažene efekte distraktora na pamćenje ciljnog podražaja (Magnussen, 2000; Magnussen i Greenlee, 1999). Na tom tragu Rademaker i sur. (2015) svoje nalaze potkrepljuju modelima dinamičkih neuralnih mreža, koji uspijevaju reproducirati razne bihevioralne fenomene putem mehanizama lokalne ekscitacije i lateralne inhibicije. Ovakvi mehanizmi, povezujući odvojene slojeve neurona za percepciju i radno pamćenje, postižu stabilnu aktivaciju u radnom pamćenju, kao i empirijski opažene interakcije između elemenata $u$ pamćenju, kao što je efekt privlačenja.

Zaključno, u ovom je radu demonstriran efekt privlačenja kod pamćenja malog broja podražaja. Četirima smo eksperimentima proučavali kako tradicionalno korištene manipulacije preciznošću radnog pamćenja utječu na efekt privlačenja kad se od sudionika traži da se dosjećaju svih prikazanih podražaja. Očekivano, kad je redoslijed dosjećanja podražaja odabiran nasumce (eksperiment 1), efekt privlačenja bio je prisutan. Efekt se održao i kad su sudionici mogli sami određivati redoslijed dosjećanja podražaja (eksperiment 2). Konačno, efekt se održao čak i kad je sudionicima unaprijed (eksperiment 3) ili unatrag (eksperiment 4) signaliziran podražaj koji će najvjerojatnije biti ispitivan prvi. Posljednji je nalaz posebno zanimljiv jer upućuje na to da su podražaji u fokusu pažnje i izvan njega jednako pod utjecajem preostalih informacija potrebnih za uspješno obavljanje zadatka. Ukupno, provedeni eksperimenti upućuje na robusnost efekta privlačenja na manipulacije preciznošću radnog pamćenja, u situaciji paralelnog prikazivanja podražaja te dosjećanja svih prikazanih podražaja.

\section{Literatura}

Adam, K. C. S., Vogel, E. K. i Awh, E. (2017). Clear evidence for item limits in visual working memory. Cognitive Psychology, 97, 79-97. https://doi.org/10.1016/j.cogpsych. 2017.07.001

Allen, R. J., Baddeley, A. D. i Hitch, G. J. (2006). Is the binding of visual features in working memory resource-demanding? Journal of Experimental Psychology: General, 135(2), 298-313. http://dx.doi.org/10.1037/0096-3445.135.2.298

Bae, G. Y., Olkkonen, M., Allred, S. R., Wilson, C. i Flombaum, J. I. (2014). Stimulusspecific variability in color working memory with delayed estimation. Journal of Vision, 14(4), 7. https://doi.org/10.1167/14.4.7 
Bays, P. M., Catalao, R. F. i Husain, M. (2009). The precision of visual working memory is set by allocation of a shared resource. Journal of Vision, 9(10), 1-11. http://dx.doi.org/10.1167/9.10.7

Bays, P. M., Gorgoraptis, N., Wee, N., Marshall, L. i Husain, M. (2011). Temporal dynamics of encoding, storage, and reallocation of visual working memory. Journal of Vision, 11(10), 1-15. http://dx.doi.org/10.1167/11.10.6

Bays, P. M. i Husain, M. (2008). Dynamic shifts of limited working memory resources in human vision. Science, 321(5890), 851-854. https://doi.org/10.1126/science.1158023

Brady, T. F. i Alvarez, G. A. (2011). Hierarchical encoding in visual working memory: Ensemble statistics bias memory for individual items. Psychological Science, 22(3), 384-392. https://doi.org/10.1177/0956797610397956

Brady, T. F. i Tenenbaum, J. B. (2013). A probabilistic model of visual working memory: Incorporating higher order regularities into working memory capacity estimates. Psychological Review, 120(1), 85-109. http://dx.doi.org/10.1037/a0030779

D'Esposito, M. i Postle, B. R. (2015). The cognitive neuroscience of working memory. Annual Review of Psychology, 66 115-142. https://doi.org/10.1146/annurev-psych-010814015031

Dubé, C., Zhou, F., Kahana, M. J. i Sekuler, R. (2014). Similarity-based distortion of visual short-term memory is due to perceptual averaging. Vision Research, 96, 8-16. https://doi.org/10.1016/j.visres.2013.12.016

Firestone, C. i Scholl, B. J. (2016). Cognition does not affect perception: Evaluating the evidence for "top-down" effects. Behavioral and Brain Sciences, 39. https://doi.org/10. 1017/S0140525X15000965

Fougnie, D., Suchow, J. W. i Alvarez, G. A. (2012). Variability in the quality of visual working memory. Nature Communications, 3, 1229. https://doi.org/10.1038/ ncomms 2237

Fritsche, M. i de Lange, F. P. (2019). Reference repulsion is not a perceptual illusion. Cognition, 184, 107-118. https://doi.org/10.1016/j.cognition.2018.12.010

Girshick, A. R., Landy, M. S. i Simoncelli, E. P. (2011). Cardinal rules: Visual orientation perception reflects knowledge of environmental statistics. Nature Neuroscience, 14(7), 926-932. https://doi.org/10.1038/nn.2831

Griffin, I. C. i Nobre, A. C. (2003). Orienting attention to locations in internal representations. Journal of Cognitive Neuroscience, 15(8), 1176-1194. https://doi.org/10.1162/ 089892903322598139

Huang, J. i Sekuler, R. (2010). Distortions in recall from visual memory: Two classes of attractors at work. Journal of Vision, 10(2), 1-27. https://doi.org/10.1167/10.2.24

Liu, T., Larsson, J. i Carrasco, M. (2007). Feature-based attention modulates orientationselective responses in human visual cortex. Neuron, 55(2), 313-323. https://doi.org/10. 1016/j.neuron.2007.06.030 
Luck, S. J. i Vogel, E. K. (1997). The capacity of visual working memory for features and conjunctions. Nature, 390(6657), 279-281. https://doi.org/10.1038/36846

Ma, W. J., Husain, M. i Bays, P. M. (2014). Changing concepts of working memory. Nature Neuroscience, 17(3), 347-356. https://doi.org/10.1038/nn.3655

Magnussen, S. (2000). Low-level memory processes in vision. Trends in Neurosciences, 23(6), 247-251. https://doi.org/10.1016/S0166-2236(00)01569-1

Magnussen, S. i Greenlee, M. W. (1999). The psychophysics of perceptual memory. Psychological Research, 62(2-3), 81-92. https://doi.org/10.1007/s004260050043

Martinez-Trujillo, J. C. i Treue, S. (2004). Feature-based attention increases the selectivity of population responses in primate visual cortex. Current Biology, 14(9), 744-751. https://doi.org/10.1016/j.cub.2004.04.028

Munneke, J., Heslenfeld, D. J. i Theeuwes, J. (2010). Spatial working memory effects in early visual cortex. Brain and Cognition, 72(3), 368-377. https://doi.org/10.1016/j.bandc. 2009.11.001

Nemes, V. A., Parry, N. R. A., Whitaker, D. i McKeefry, D. J. (2012). The retention and disruption of color information in human short-term visual memory. Journal of Vision, 12(1), 26. https://doi.org/10.1167/12.1.26

Nemes, V. A., Whitaker, D., Heron, J. i McKeefry, D. J. (2011). Multiple spatial frequency channels in human visual perceptual memory. Vision Research, 51(23-24), 2331-2339. https://doi.org/10.1016/j.visres.2011.09.003

Orhan, A. E. i Jacobs, R. A. (2013). A probabilistic clustering theory of the organization of visual short-term memory. Psychological Review, 120(2), 297. https://doi.org/10.1037/ a0031541

Pelli, D. G. (1997). The VideoToolbox software for visual psychophysics: Transforming numbers into movies. Spatial Vision, 10(4), 437-442.

Pertzov, Y., Bays, P. M., Joseph, S. i Husain, M. (2013). Rapid forgetting prevented by retrospective attention cues. Journal of Experimental Psychology: Human Perception and Performance, 39(5), 1224. http://dx.doi.org/10.1037/a0030947

Pratte, M. S., Park, Y. E., Rademaker, R. L. i Tong, F. (2017). Accounting for stimulusspecific variation in precision reveals a discrete capacity limit in visual working memory. Journal of Experimental Psychology: Human Perception and Performance, 43(1), 6-17. https://doi.org/10.1037/xhp0000302

Rademaker, R. L., Bloem, I. M., De Weerd, P. i Sack, A. T. (2015). The impact of interference on short-term memory for visual orientation. Journal of Experimental Psychology: Human Perception and Performance, 41(6), 1650-1665. https://doi.org/10.1037/ xhp0000110

Schmidt, B. K., Vogel, E. K., Woodman, G. F. i Luck, S. J. (2002). Voluntary and automatic attentional control of visual working memory. Perception \& Psychophysics, 64(5), 754763. https://doi.org/10.3758/BF03194742 
Suchow, J. W., Fougnie, D. i Alvarez, G. A. (2017). Looking inward and back: Real-time monitoring of visual working memories. Journal of Experimental Psychology: Learning, Memory, and Cognition, 43(4), 660-668. https://doi.org/10.1037/xlm 0000320

Taylor, R. i Bays, P. M. (2018). Efficient coding in visual working memory accounts for stimulus-specific variations in recall. Journal of Neuroscience, 38(32), 7132-7142. https://doi.org/10.1523/JNEUROSCI.1018-18.2018

Theeuwes, J., Kramer, A. F. i Irwin, D. E. (2011). Attention on our mind: The role of spatial attention in visual working memory. Acta Psychologica, 137(2), 248-251. https://doi.org/10.1016/j.actpsy.2010.06.011

Webster, M. A. (2015). Visual adaptation. Annual Review of Vision Science, 1, 547-567. https://doi.org/10.1146/annurev-vision-082114-035509

Wei, X. X. i Stocker, A. A. (2017). Lawful relation between perceptual bias and discriminability. Proceedings of the National Academy of Sciences, 114(38), 1024410249. https://doi.org/10.1073/pnas.1619153114

Wilken, P. i Ma, W. J. (2004). A detection theory account of change detection. Journal of Vision, 4(12), 1120-1135. https://doi.org/10.1167/4.12.11

\title{
Attraction Effect in the Visual Working Memory
}

\begin{abstract}
One of the basic characteristics of visual working memory (VWM) is that recall precision declines with the number of items to be memorised. This finding is interpreted as a consequence of the allocation of a limited pool of resources, whereby the amount of resources allocated to each item drops with each additional stimulus. Recent studies show that recall in VWM tasks also depends on the characteristics of the stimulus set which is to be memorised. Specifically, when memorising simple visual features of two stimuli (e.g. their orientations), the recall of one stimulus's features is marked by a systematic bias towards the other stimulus's features. In this study, we wanted to examine how robust this effect is to experimental manipulations of memory precision. In four experiments, participants $(N=33)$ memorised and recalled the orientations of two simultaneously presented stimuli. In the first experiment, the recall order was chosen at random. In the second, participants had to choose the recall order themselves. In the third and fourth experiments, recall order was again chosen at random, but participants were presented with a cue before (exp. 3) or after (exp. 4) the stimuli were displayed, which indicated which of the stimuli is most likely to be recalled first. The attraction effect was observed in all four experiments and affected the recall of both stimuli. This study demonstrates the robustness of the attraction effect in VWM, implying that the mechanisms underlying the effect are not susceptible to correction, or in other words, that it is a part of the fundamental processes of coding visual stimuli.
\end{abstract}

Keywords: visual working memory, attraction effect, orientation recall, cueing

Primljeno: 30.11.2018. 